\title{
MODELLING EFFLUENT ASSIMILATIVE CAPACITY OF IKPOBA RIVER, BENIN CITY, NIGERIA
}

\author{
C. M. Chiejine ${ }^{1,}{ }^{*}$, A. C. Igboanugo ${ }^{2}$ and L. I. N. Ezemonye ${ }^{3}$ \\ 1Dept of Electrical/Electronic Engineering, Delta State Polytechnic, OGWashi-UKu, Delta State, NiGERIA

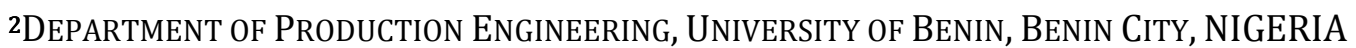 \\ 3DEPARTMENT OF ANIMAL AND ENVIRONMENTAL BIOLOGY, UNIVERSITY OF BENIN, BENIN City. NIGERIA \\ E-mail Addresses:1 pstchiejine@yahoo.com,2dracigboanugo@yahoo.com,3ezemslaw@yahoo.com
}

\begin{abstract}
The sheer display of reprehensible propensity on the part of public hospitals, abattoirs, breweries and city dwellers at large to discharge untreated waste, debris, scum and, in particular, municipal and industrial effluents into Ikpoba River has morphed into a situation whereby the assimilative capacity of the river has reached a record level. The seeming quietism and clinical posture of the relevant Environmental Agency to this pathological condition is sickening and in any case seen as remiss on their part. This paper seeks to determine the assimilative capacity of the river with a view to articulating policy-proposal stream in the instance that its value is unsafe for ichthyofaunal beings and humans. A combination of basic Streeter-Phelp equation and monograph of Fair et al. were used for the determination of the assimilative capacity and the maximum allowable biological oxygen demand (BOD) load discharged into the river from three identified point sources of wastewater and for three different seasons in Nigeria (i.e. rainy, dry and harmattan seasons). Results indicate that in all the segments studied, the Fair ratio (selfpurification factor) is less than unity, indicating the predominance of deoxygenation rate over reaeration rate. Reaeration rate ranges over all real values from 0.641 day $^{-1}$ to $0.693 \mathrm{day}^{-1}$, while deoxygenation rate ranges between 0.718 day-1 $^{1}$ and 0.839 day $^{1}$; a condition which indicates a poor assimilative capacity potential. Moreover, a higher assimilative capacity was obtained for rainy season for all the segments studied, with sampling point 3 (Guinnessharmattan and dry season) showing an overall worse assimilative capacity and poor maximum allowable BOD of $8.1 \times 10^{9}, 1.28 \times 10^{10}$ and $5.60 \times 10^{9} \mathrm{~kg} /$ day respectively. In a way, the determination of the assimilative capacity of Ikpoba River is a landmark in the history of the river pollution. It beggars belief that we live down the harrowing pathological condition of the river without recognizing its wider implications.
\end{abstract}

Keywords: Assimilative capacity, Fair ratio, untreated waste, pathological condition, maximum allowable BOD load

\section{INTRODUCTION}

Effluent plumes, municipal wastes, scum, and surface runoffs are often channeled into rivers, especially in developing countries where laws on environmental regulation are not strictly enforced [1].These loadings in the river deplete its dissolved oxygen (DO) leading to the development of a long stretch of dissolved oxygen (DO) sag zone that is detrimental to aquatic lives. Besides depletion of DO, river pollution appears to be associated with spread of water borne diseases.

River water serves several purposes to communities settling around its course such as agricultural, industrial and domestic utilities. Thus, river pollution beyond its assimilative capacity is quite expensive to treat in order for it to meet the aforementioned needs of the communities. It is therefore important that assimilative capacity of surface flowing water bodies be determined. Further, in order to articulate and develop a reliable water quality management programme for a polluted water body, a sound understanding of the correlation between the waste discharge into it and its capacity to assimilate same without compromising its original water quality is necessary. This can provide more logical ground for water quality regulation for the particular river rather than working on a more general and uniform rules 
which may not be applicable to every water body within the jurisdiction of the regulatory body. It is therefore imperative that this study be carried out on Ikpoba River, Benin city, Nigeria which has been severally confirmed to be polluted [2-5].

While a number of studies have expressed concern about the polluted status of Ikpoba River and addressed various aspects of its pollution status, albeit with hardly appropriate analytics, the mechanics of the gradual development of its assimilative capacity has, to the best our knowledge, been rarely explored. The study[6] provides some insight regarding the need for urgent proactive measures to forestall imminent epidemic arising from the effects of pollution on the river. The assessment of the assimilative capacity of a river is necessary before any efficient management programme of the river can be developed[7].

The pioneering work of [8] which investigates the relationship between dissolved oxygen (DO) resources and the measured organic waste decay giving rise to biochemical oxygen demand (BOD) from which the classic dissolved oxygen sag model was produced, has been very pivotal in the analysis and determination of capacity of streams to assimilate pollution of organic wastes.

Since the classical theory of [8], many investigators have applied the theory to water quality management studies and several modifications as well had been proposed for various scenarios [9-14]. Deserving of note are the works [15-18] which claim that apart from the biochemical oxidation of organic matter and atmospheric reaeration of river water, that there are other factors in a water body which affect the DO-BOD relationship. According to them these factors are:

i. removal of oxygen by respiration of plankton and rooted plants;

ii. removal of oxygen from water by purging action of gases rising from benthal layer;

iii. removal of oxygen from water by diffusion into the benthal layer to satisfy oxygen demand in the aerobic zone of this layer;

iv. removal of BOD by sedimentation and adsorption;

v. addition of BOD by local runoff;

vi. addition of BOD along a river stretch by scour of bottom deposits or diffusion of partly decomposed organic products from the benthal layer into the waters above; vii. addition of oxygen by photosynthetic action of plankton and fixed plants; and

viii. continuous redistribution of BOD and DO by the effect of longitudinal dispersion.

Over the years, several efforts had been made to produce several complex water quality models which tend to describe the changes in dissolved oxygen (DO) as occasioned by changes in BOD. Examples of such complex models are QUAL 2E by [19] and WASP6 by [20]. The foregoing notwithstanding, however, the classic study [8] and its various modifications have remained the most widely used set of models [14]. The study [21] suggests that effective water management program should use models which are easily interpretable by decision makers. The current study has therefore applied basic Streeter-Phelps model to determine the assimilative capacity of Ikpoba River. This study therefore seeks to investigate the dynamics of evolution of assimilative capacity and the maximum allowable BOD of the river under the existing effluent discharge into it. The findings will provide a guide towards a pragmatic approach in maintaining water quality standards for water quality managers and regulatory bodies.

\section{MATERIALS AND METHODS}

\subsection{Study Site}

Ikpoba River is located in Benin City, Nigeria (Figure 1). As can be seen from the figure, the river flows from top to bottom of the map, traversing the points $\mathrm{P}_{1}, \mathrm{P}_{2}$, $\mathrm{P}_{3}$ and $\mathrm{P}_{4}$, which are the effluent discharge points, where samples were taken for the study. It navigates the city, flowing from North to South. Due to immense direct effluent loading of industrial effluents, domestic and agricultural activities, runoffs from municipal sewage system as well as the discharge of diverse abattoir wastes into the river, its water quality has been profoundly impaired.

The current study investigates the stretch of the river which is sandwiched between a public health institution whose wastes leach into the river and some large breweries which also channel their effluent discharge into it. Also, along the river bank of this reach is located a public abattoir which discharges diverse abattoir wastes, including cow blood and excreta. This stretch is estimated to be about $10 \mathrm{~km}$. 


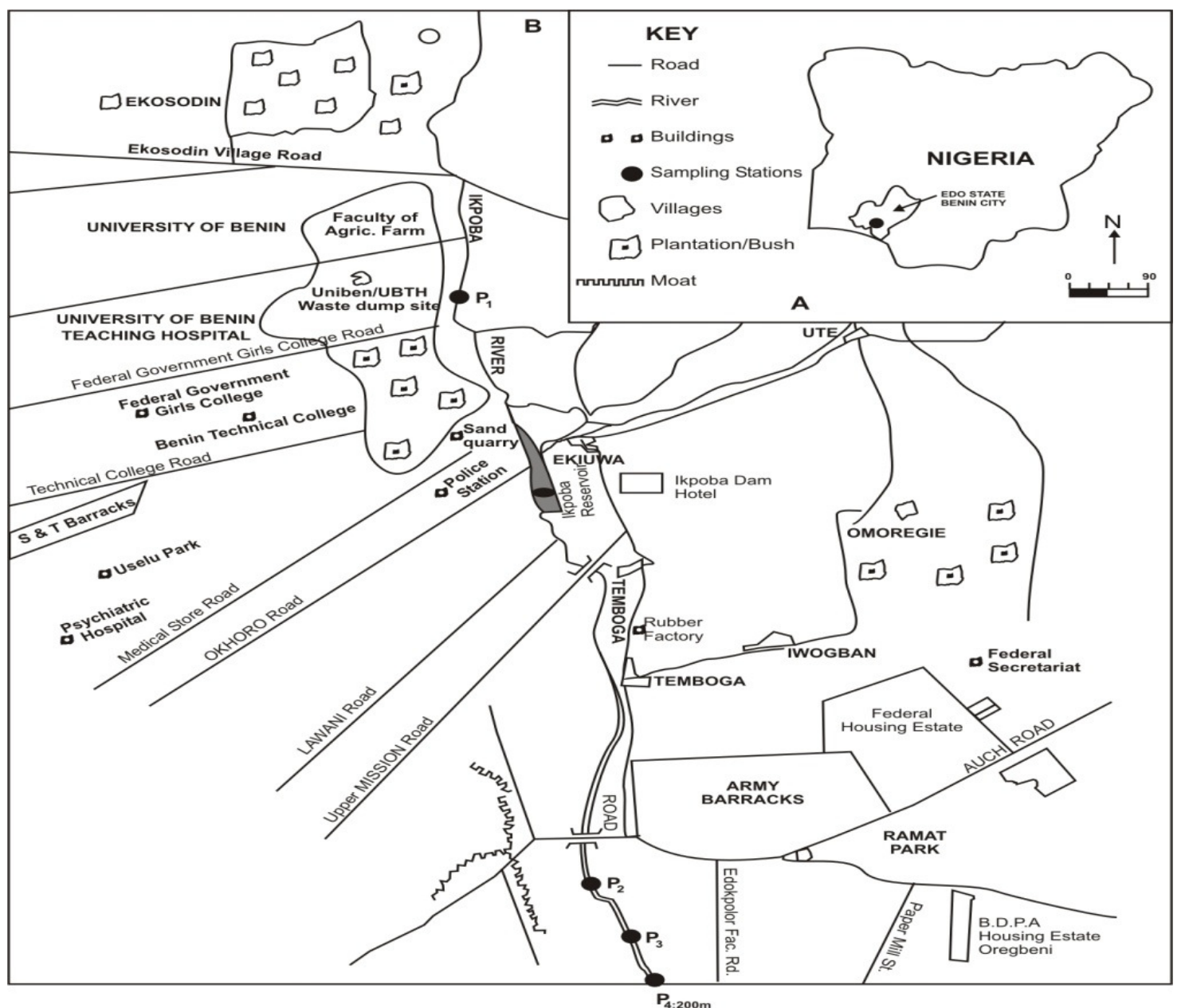

Figure 1: The study area: A - Map of Nigeria showing Benin City in Edo State, B - Map of Ikpoba River Showing two Sampling Stations

\subsection{Sampling Design and Measurements}

It has been established that velocity, depth, temperature and discharge are among the natural factors affecting the assimilative capacity of water bodies [22].

Based on this premise therefore, at each sampling station, Swoffer ${ }^{\circledR}$ meter was used to determine the speed of the river. Depth was taken at the various sampling points as well using Speedtech ${ }^{\circledR}$ depth sounder, while the temperature of the samples were taken in situ using mercury-in-glass thermometer (0$100^{\circ} \mathrm{C}$ ). The cross-section of the river was measured by stretching a tape across its width. The river water samples for physiochemical, microbiological and heavy metal analysis were collected from four predetermined points. At each point, upstream and downstream, the samples for physiochemical and microbiological analyses were collected with $50 \mathrm{ml}$ reagent bottles which were washed with distilled water and further rinsed with water collected at the sample point before the collection of samples. Oxygen fixation for the specimens was done with Winkler solutions A and B. Distilled-water-diluted nitric acid was required to maintain the oxidation state of the elements and also to prevent materials from adhering to the walls of the container. The samples meant for heavy metal analyses were collected with 1 litre plastic container. These were done in June and December 2012 (i.e. raining season and dry season respectively). Upon handing over the samples to the personnel of the laboratory where the analyses were carried out they removed the samples from the ice chest and had them frozen prior to subsequent chemical analysis in line with fundamentals of field studies. All the water quality parameters were analyzed using appropriate standard methods namely APHA, HATCH Digital titration and Determination Bacteriology as specified in [23-25].All the laboratory analyses were done in Earth Quest International Limited, Warri, Nigeria.

\subsection{Method of analysis of Data}

In this study, the maximum BODu load into the river and its assimilative capacity were determined by a 
combination of the basic Streeter-Phelps equation and the monograph of Fair et al. This is based on the fact that the prime indicator of water quality of a river is its DO level. So the impact of BOD load on DO was investigated.

The basic Streeter-Phelps equation was considered adequate for this analysis due to its long history of use, ease of computation, wide acceptability and applicability in spite of its short comings particularly the assumption of steady state assimilation of the pollution load. Moreover, according to [26], there are no effective alternative formulations with superior range of conditions.

\subsubsection{DO Saturated Value}

The calculation of the DO saturation value $\left(C_{s}\right)$ for various water temperatures as introduced by [27] is made feasible by the use of the following empirical equation:

$$
\begin{gathered}
C_{s}=14.541233-0.3928026 T+0.00732326 T^{2} \\
+0.00006629 T^{3}
\end{gathered}
$$

\subsubsection{Reaeration Rate Constant $\left(K_{2}\right)$}

According to study [28], the reaeration rate constant $\left(\mathrm{K}_{2}\right)$, which is a function of the diffusivity of oxygen in water, depth of river, velocity of river, and 'temperature of river, can be calculated with equation (2) that follows, which is generally applicable to streams with a depth of greater than 1.52 meters. This makes it applicable to the current study. In that regard, it is justifiable to apply the equation to this case study as follows [28]:

$$
K_{2_{(T)}}=3.93 V^{\frac{1}{2}} \frac{(1.024)^{(T-20)}}{H^{\frac{3}{2}}}
$$

where 3.93 is the diffusivity of oxygen in water, $\mathrm{H}$ is the average depth in metres, $\mathrm{V}$ is the Flow velocity in $\mathrm{ms}^{-1}$, and $\mathrm{T}$ is the temperature in degree Celsius.

\subsubsection{Deoxygenation Cofficient $\left(K_{1}\right)$}

Also, according to [28] the deoxygination coefficient $\left(\mathrm{K}_{1}\right)$ is calculated with the formula [28]:

$$
K_{1_{(T)}}=3.93 V^{\frac{1}{2}} \frac{(1.048)^{(T-20)}}{H^{\frac{3}{2}}}
$$

The critical DO deficit,

$$
\mathrm{D}_{\mathrm{c}}(\mathrm{mg} / \mathrm{l})=C_{S}-C_{c}
$$

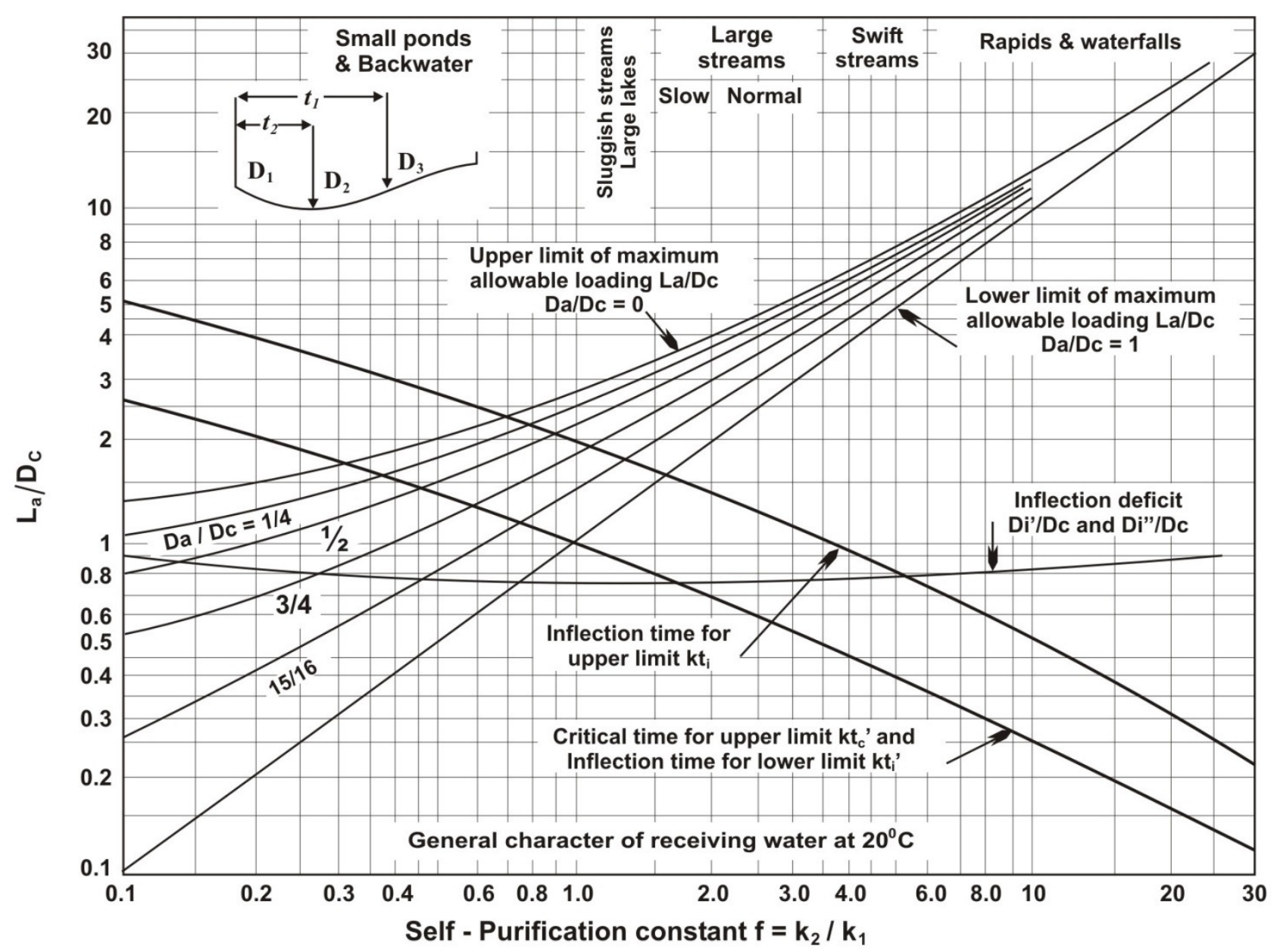

Figure 2: The monograph of allowable BODu loading of the receiving waters, [29]. 
Equations (4) to (9) were sourced from [30], wherein $C_{c}$ is the critical dissolved oxygen concentration (minimum acceptable)

The initial dissolved oxygen deficit:

$$
\mathrm{D}_{\mathrm{a}}(\mathrm{mg} / \mathrm{l})=C_{S}-C_{a}
$$

where $C_{a}$ is the initial dissolved oxygen concentration (prior to discharge point)

Self-purification factor:

$$
(f)=\frac{K_{2}}{K_{1}}
$$

$L_{a} / D_{c}$ ratio, obtained from the monograph of Fair et al. as a function of purification factor $(f)$ and the ratio $D_{a} / D_{c}$

$L_{a}$ is the allowable concentration of BOD just after the discharge point; from equation:

$$
L_{a}=D_{c}\left(L_{a} / D_{c}\right)
$$

$B_{u}$ is the maximum allowable $\mathrm{BOD}_{\mathrm{u}}$ load discharge at the river and it was calculated with the relationship:

$$
B_{u}=24 \times 3600 \mathrm{x}\left(\left(Q_{r}+Q_{w}\right) L_{a}-Q_{r} L_{p}\right) / 1000
$$

where $Q_{r}$ is the river flow rate; $Q_{w}$ is the discharge flow rate

Assimilative Capacity (AC) was calculated with relationship:

$$
\mathrm{AC}=24 \times 3600 \times L_{a} \times Q_{r} / 1000
$$

\section{THEORETICAL CONCEPT}

Every fresh water body has saturated dissolved oxygen which is a function of its ambient temperature and total dissolved salt present in it [31]. When a river with initial saturated dissolved oxygen $\mathrm{Do}_{\mathrm{s}}$ is polluted, the dissolved oxygen (DO) content starts to diminish with initial deficit $\mathrm{DO}_{o}$ and continues up to a certain distance downstream when it begins to recover. This variation of dissolved oxygen deficit with the distance downstream vis-à-vis the time of flow from the point of pollution is illustrated by the oxygen sag curve (Figure 2).

The point of minimum DO, being the maximum deficit, which is also called the critical deficit $\mathrm{DO}_{\mathrm{c}}$ is the point of inflexion of the curve. It is considered the major point of the oxygen sag analysis.

The capacity of a river to oxidize organic wastes is determined by its oxygen dynamics as described by the study [7] in the following equation:

In terms of the deficit with time,

DO deficit $=$ saturated DO - DO in Water i.e.

$$
\begin{aligned}
& \mathrm{D}=\mathrm{S}-\mathrm{C} \\
& \frac{d D}{d t}=K_{1} Z-K_{2} D
\end{aligned}
$$

Where $Z=L e^{-K_{11}}$. Equation (11) is the StreeterPhelps steady state equation.

Substituting and integrating yields the following equations, referred to as the basic Streeter-Phelps equations

$$
\begin{gathered}
D_{t}=\frac{K_{1} L_{o}}{K_{2}-K_{1}}\left(e^{-K_{1} t}-e^{-K_{2} t}\right)+D_{o} e^{-K_{2} t} \\
\frac{d D_{o}}{d t}=K_{1} L_{o} e^{-K_{1} t}-K_{2} D=0 \\
D O_{c}=\frac{K_{1}}{K_{2}} L_{o} e^{-K_{1} t} \\
t_{c}=\frac{1}{K_{2}-K_{1}} \operatorname{In}\left\{\frac{K_{2}}{K_{1}}\left[1-D_{o} \frac{\left(K_{2}-K_{1}\right)}{K_{1} L_{o}}\right]\right\}
\end{gathered}
$$

In the above equations, $D_{t}=$ DO deficiency at any point in time $(\mathrm{mg} / \mathrm{l}), \mathrm{K}_{1}$ is the oxygen consumption coefficient to base $e$ (per day), $\mathrm{K}_{2}$ is the reaeration rate constant to base $e$ (per day), $\mathrm{L}_{o}$ is the initial BOD load $(\mathrm{mg} / \mathrm{l}), \mathrm{D}_{\mathrm{o}}$ is the initial DO deficiency and $\mathrm{t}$ is the time of travel(day)as $t=\frac{x}{v}$ in which $x$ is the distance from the upstream point of discharge; $v$ is the velocity (m/day)and $\left(t_{c}, D_{c}\right)$ is critical point at which the rate of change of DO equals zero during downstream movement.

\section{RESULTS AND DISCUSSION}

\subsection{Assimilative Capacity}

The self-purification factors used in this study are the deoxygenation rate coefficient $\left(\mathrm{K}_{1}\right)$ and the reaeration rate coefficient $\left(\mathrm{K}_{2}\right)$. These were used to determine the Fair ratio, $f=\left(\frac{K_{1}}{K_{2}}\right)$. The Fair ratio depicts the degree of preponderance of reaeration over deoxygenation [32]. The results in Table 1 which was obtained by the method of [30] show that the reaeration rate ranges between 0.641 day $^{-1}$ and 0.693 day $^{-1}$ for different segments of the river, and for the different seasons considered, while the deoxygenation rate ranges from 0.718 day $^{-1}$ to 0.839 day $^{-1}$.

The Fair ratio $(f)$ is less than unity in all of the segments of the river studied and for all of the seasons. The import of this is that deoxygenation predominates reaeration in the stretch of the river studied. Furthermore, it can be seen from the results in Table 1 that the assimilative capacity and the maximum allowable BOD are higher during the rainy season for all the segments studied. This conforms to reality consequent upon dilution factor. The rainy season provides the river with sufficient water for dilution. This makes the DO level to be farther away from the critical point due to the availability of 
relatively sufficient DO in the river before the introduction of the wastewater. Therefore, the assimilative capacity in the rainy season is increased. Again, at sampling point 3, results reveal that the maximum allowable BOD are $7.39 \times 10^{9} \mathrm{~kg} /$ day, $5.60 \times 10^{9} \mathrm{~kg} /$ day and $1.05 \times 10^{10} \mathrm{~kg} /$ day for the dry, harmattan and rainy seasons respectively, making it the lowest relative to the other sampling points. This, perhaps, explains why one can hardly notice any fishing activities around this segment of the river portraying a virtually non-existence of ichtyofaunal beings due to high level of eutrophication. Again, an overall least assimilative capacity of $8.1 \times 10^{9}$, $1.28 \times 10^{10}$ and $1.07 \times 10^{10} \mathrm{~kg} /$ day were obtained for the aforementioned three different seasons respectively at sampling point 3 . It is obvious therefore that there is an urgent need for relevant regulatory bodies like The Nigeria Environmental Standard and Regulations Enforcement Agency (NESREA) to weigh in with strict enforcement of existing regulatory laws to forestall an epidemic.

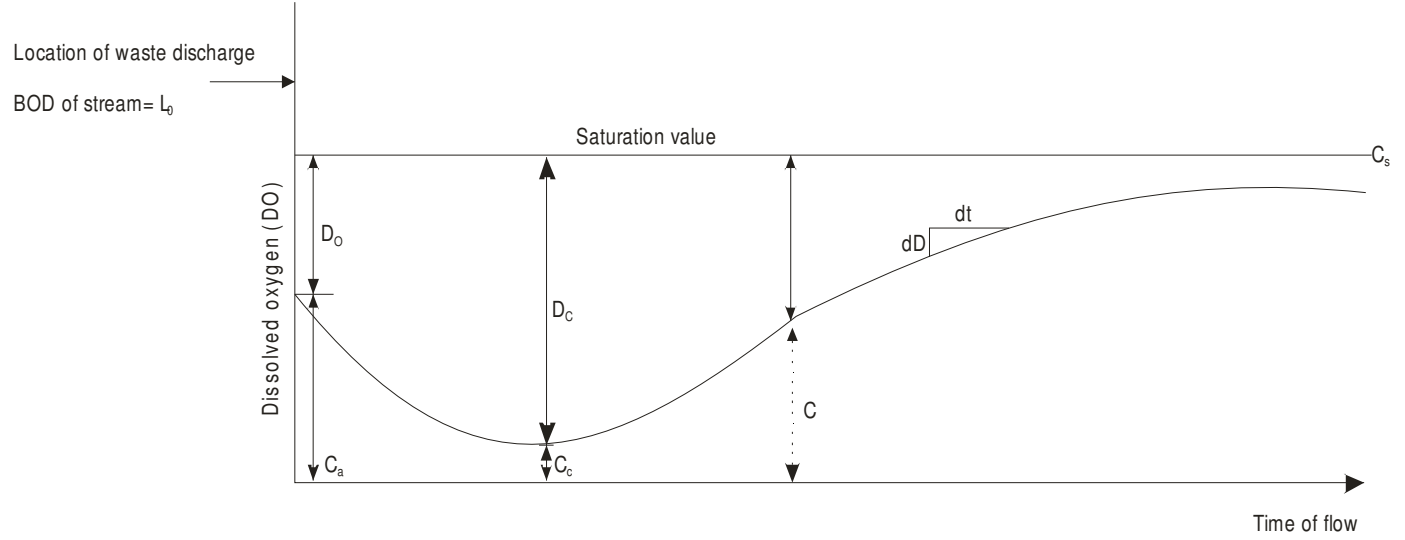

Figure 2.Deoxygenation, reoxygenation and oxygen Sag curve.

$$
\mathrm{D}=\mathrm{C}_{\mathrm{s}}-\mathrm{C}_{\mathrm{a}}, \mathrm{D}_{\mathrm{o}}=\mathrm{C}_{\mathrm{s}}-\mathrm{C}_{0}, \mathrm{D}_{\mathrm{c}}=\mathrm{C}_{\mathrm{s}}-\mathrm{C}_{\mathrm{c}}
$$

where: $D=$ dissolved oxygen deficits in $\mathrm{mg} / \mathrm{l}, C_{s}=$ saturated concentration of dissolved oxygen in $\mathrm{mg} / \mathrm{l}, C_{a}=$ actual concentration of dissolved oxygen in $\mathrm{mg} / \mathrm{l}$, $D_{o}=$ initial $D O$ deficit in $\mathrm{mg} / \mathrm{l}$ which is $D O$ deficit at $t=0, D_{c}$ critical $D O$ deficit in $\mathrm{mg} / \mathrm{l}, C_{c}=c r i t i c a l ~ D O$, in $m g / l$.

Table1.Water Quality Determinants for Ikpoba River by Seasons

\begin{tabular}{|c|c|c|c|c|c|c|c|c|c|c|c|}
\hline \multirow[b]{2}{*}{ Input/output data } & \multirow[b]{2}{*}{ symbol } & \multirow[b]{2}{*}{ Unit } & \multicolumn{3}{|c|}{ UBTH } & \multicolumn{3}{|c|}{ EWAH RD.JUNCTION } & \multicolumn{3}{|c|}{ GUINNESS } \\
\hline & & & $\begin{array}{c}\text { Dry } \\
\text { Season }\end{array}$ & $\begin{array}{c}\text { Harmattan } \\
\text { season }\end{array}$ & $\begin{array}{l}\text { Rainy } \\
\text { season }\end{array}$ & $\begin{array}{c}\text { Dry } \\
\text { season }\end{array}$ & $\begin{array}{c}\text { Harmattan } \\
\text { season }\end{array}$ & $\begin{array}{l}\text { Rainy } \\
\text { season }\end{array}$ & $\begin{array}{c}\text { Dry } \\
\text { season }\end{array}$ & $\begin{array}{l}\text { Harmattan } \\
\text { season }\end{array}$ & $\begin{array}{l}\text { Rainy } \\
\text { season }\end{array}$ \\
\hline Temperature of river & $\bar{T}$ & ${ }^{\circ} \mathrm{C}$ & 23.6 & 25.2 & 22.6 & 26.8 & 27.5 & 25.9 & 28.2 & 27.0 & 25.9 \\
\hline $\begin{array}{l}\text { Initial DO prior to } \\
\text { discharge point }\end{array}$ & $\mathrm{C}_{\mathrm{a}}$ & $\mathrm{mg} / \mathrm{l}$ & 7.9 & 7.6 & 8.5 & 7.0 & 6.6 & 7.4 & 7.1 & 6.8 & 7.8 \\
\hline DO after discharge & DO & $\mathrm{mg} / \mathrm{l}$ & 7.8 & 7.6 & 7.8 & 6.7 & 6.2 & 6.2 & 0.3 & 0.2 & 0.6 \\
\hline Critical DO & $\mathrm{C}_{\mathrm{c}}$ & $\mathrm{mg} / \mathrm{l}$ & 5.0 & 5.0 & 5.0 & 5.0 & 5.0 & 5.0 & 5.0 & 5.0 & 5.0 \\
\hline Saturated DO & $\mathrm{C}_{\mathrm{s}}$ & $\mathrm{mg} / \mathrm{l}$ & 8.47 & 8.23 & 8.63 & 8.0 & 7.9 & 8.1 & 7.8 & 8.0 & 8.1 \\
\hline $\mathrm{DC}=\mathrm{C}_{\mathrm{s}}-\mathrm{C}_{\mathrm{c}}$ & $\mathrm{DC}$ & $\mathrm{mg} / \mathrm{l}$ & 3.47 & 3.32 & 3.36 & 3.0 & 2.9 & 3.1 & 2,8 & 3.0 & 3.1 \\
\hline$D_{a}=C_{s}-C_{a}$ & $\mathrm{Da}_{\mathrm{a}}$ & $\mathrm{mg} / \mathrm{l}$ & 0.57 & 0.63 & 0.13 & 1.0 & 1.3 & 0.7 & 0.7 & 1.2 & 0.3 \\
\hline $\begin{array}{l}\text { Decay rate constant at } \\
\qquad \mathrm{T}^{\circ} \mathrm{C}\end{array}$ & $\mathrm{K}_{1(\mathrm{~T})}$ & day $^{-1}$ & 0.785 & 0.727 & 0.718 & 0.785 & 0.810 & 0.753 & 0.839 & 0.790 & 0.753 \\
\hline Reaeration rate $\mathrm{T}^{\circ} \mathrm{C}$ & $\mathrm{K}_{2(\mathrm{~T})}$ & day $^{-1}$ & 0.671 & 0.645 & 0.641 & 0.671 & 0.680 & 0.656 & 0.693 & 0.67 & 0.656 \\
\hline $\mathrm{BOD}_{5}$ (river water) & & $\mathrm{mg} / \mathrm{l}$ & 4.1 & 3.10 & 3.4 & 0.6 & 0.8 & 1.3 & 1.1 & 1.3 & 1.5 \\
\hline $\mathrm{BOD}_{\mathrm{u}}$ & $L_{p}$ & $\mathrm{mg} / \mathrm{l}$ & 5.3 & 6.7 & 5.9 & 3.8 & 4.9 & 4.2 & 16.2 & 17.4 & 13.1 \\
\hline River flow rate & $Q_{r}$ & $\mathrm{~m}^{3} /$ day & 13996800 & 25920000 & 15246100 & 13996800 & 25920000 & 15246100 & 13996800 & 13996800 & 15246100 \\
\hline Discharge flow rate & $f^{Q_{w}}$ & $m^{3} /$ day & 2160000 & 1728000 & 2160000 & 1120000 & 1120000 & 6200000 & 4160000 & 1728000 & 2160000 \\
\hline Self -purification factor & $=\frac{K_{2}}{K_{1}}$ & & 0.85 & 0.89 & 0.89 & 0.85 & 0.84 & 0.87 & 0.83 & 0.85 & 0.87 \\
\hline$D_{a} / D_{c}$ & $D_{a} / D_{c}$ & & 0.16 & 0.2 & 0.04 & 0.33 & 0.45 & 0.23 & 0.25 & 0.4 & 0.1 \\
\hline$L_{a} / D_{c}$ & $L_{a} /_{D_{c}}$ & & 2.5 & 2.3 & 2.7 & 2.5 & 1.9 & 2.6 & 2.4 & 1.9 & 2.6 \\
\hline$L_{a}$ & $L_{a}$ & $\mathrm{mg} / \mathrm{l}$ & 8.7 & 8.7 & 9.8 & 7.5 & 4.6 & 8.1 & 6.7 & 5.7 & 8.1 \\
\hline Maximum allowable $\mathrm{BOD}_{\mathrm{u}}$ & $\mathrm{B}_{\mathrm{u}}$ & Kg/day & $5.74 \times 10^{9}$ & $4.48 \times 10^{9}$ & $6.55 \times 10^{9}$ & $5.87 \times 10^{9}$ & $2.21 \times 10^{8}$ & $6.27 \times 10^{9}$ & $7.39 \times 10^{9}$ & $5.6 \times 10^{9}$ & $1.05 \times 10^{10}$ \\
\hline Assimilative capacity (AC) & $A C$ & Kg/day & $1.05 \times 10^{10}$ & $1.95 \times 10^{10}$ & $1.29 \times 10^{10}$ & $9.07 \times 10^{9}$ & $1.03 \times 10^{9}$ & $1.07 \times 10^{10}$ & $8.1 \times 10^{9}$ & $1.28 \times 10^{10}$ & $1.07 \times 10^{10}$ \\
\hline
\end{tabular}


An earlier study by the authors [33] analysed the relationship between the heavy metals and the other pollution determining parameters. It was discovered that heavy metals, namely Cadmium (Cd), Copper $(\mathrm{Cu})$, Iron $(\mathrm{Fe})$ and Lead $(\mathrm{Pb})$ correlate negatively with $\mathrm{pH}$ and $\mathrm{DO}$ on the one hand but positively with BOD, COD and Fecal coliform on the other. One possible interpretation of this correlation is that the presence of heavy metals tends to cause oxidation reaction that depletes dissolved oxygen (DO) in the river. Therefore the more the heavy-metal-bearing effluents are injected into the river, the more the abundance of Feacal coliform, COD, and BOD. As the loading abates, so do the Feacal Coliform, BOD and COD proportionately decrease. In other words, there is positive correlation between heavy metals BOD, COD and Fecal Coliform.

However, the reverse is the case for correlation between heavy metals on the one side and $\mathrm{pH}$ and DO on the other. This latter case involves inverse relationship in the sense that the more the heavy metals which come from effluent loading, the more the oxidation reaction that depletes the DO. The discernment of this relationship was made possible by the correlation analysis statistical methodology applied in the study under reference.

\subsection{Articulation of Policy Proposal}

Pollution, arising from urbanization and industrialization around a segment of Ikpoba River, has morphed into an unhealthy ecosystem capable of causing an epidemic [33]. The assimilative capacity which is an index of the level of the perceived pollution is about $8.1 \times 10^{9} \mathrm{~kg} /$ day $^{-1}$ within associated maximum allowable BOD of $1.02 \times 10^{9} \mathrm{~kg} / \mathrm{day}^{-1}$ derived from sample observation of $16.2 \mathrm{mg} / \mathrm{l}$ for station 3 downstream. This value, although considered to be still within limits of maximum allowable for Nigeria (see table on appendix for more details) needs to be put in check to avoid escalation. Moreover, there is pronounced oxygen sag at station 3 downstream giving a least value of $0.2 \mathrm{mg} / \mathrm{l}$ as against acceptable value of $5 \mathrm{mg} / \mathrm{l}$ [34]. This development causes serious degradation of assimilative capacity in the river portion under reference. Our results show that the river tends to recover from the oxygen sag effects (sharp decrease in DO and hence degraded assimilative capacity) after some $200 \mathrm{~m}$ downstream and these figures are considered quite unsafe.
Following the finding from this study, the following recommendations are suggested.

\section{RECOMMENDATIONS:}

1. Individuals and corporate organisations found to be committing infractions of the existing regulatory environmental laws should be prosecuted to serve as deterrent to others. There has not been any recorded case of offenders being prosecuted.

2. Although existing regulations require that industrial effluents should be treated before being discharged into the river, it has been an exception rather than the rule. Environmental laws should be made enforceable.

3. The foregoing problem-solution stream is hereby proposed as policy agenda for Nigeria Environmental Standard and Regulations Enforcement Agency (NESREA).

\section{CONCLUSION}

The objective of this study was to determine the assimilative capacity and the maximum allowable BOD discharge onto the urbanized potion of Ikpoba River which has been inundated with diverse industrial effluents and municipal wastewater discharge. The results show that the deoxygenation rate in the river dominates oxygenation rate, thus portraying the river as highly polluted with poor assimilative capacity potential.

Furthermore, for each of the segments studied, rainy season shows a higher tendency for minimum acceptable dissolved oxygen concentration than both the dry and harmattan seasons.

The objectives of this study, as stated earlier, were therefore fully realized having successfully determined the assimilative capacity and the maximum allowable BOD discharge in the reach of the river studied. It is therefore hoped that this work provides needed scientific and empirical basis for Nigeria Environmental Standard and Regulations Enforcement Agency (NESREA), stakeholders and decision makers in general for decisions concerning the water quality problems and surveillance programmes and other regulatory activities on surface water in general and Ikpoba River in particular.

\section{REFERENCES}

1. World Bank (1995). Nigeria Strategic Options for Redressing Industrial Pollution. World Bank 


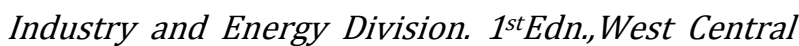
Africa Department, Annexes pp 60-62

2. Benker-Coker, M.0; Ojor, 0.0 (1995). Effects of Slaughter House on the Quality of Ikpoba River, Benin City, Nigeria. BioresourceTechnology 52 :5-12

3. Eguaje, J.A (1993). Studies on the Effects of Brewery Effluent on Ikpoba River. Paper presented at a Conference of Waste Management, Edo state Environmental Protection Agency, Benin City. August $6^{\text {th }} 1993$

4. Ekhaise, F.O and Anyansi, C.C (2005). Influence of Breweries Effluent Discharge on the Microbiological and Physicochemical Quality of Ikpoba River, Nigeria. African Journal of Biotechnology 4 (10) pp. 1062-1065

5. Oguzie, F.A and Okhagbuzo, G.A (2010). Concentration of Heavy Metals in Effluent Discharges Downstream of Ikpoba River in Benin City, Nigeria. African Journal of Biotechnology 9 (3)pp. 319-325

6. Igboanugo, A.C and Chiejine, C.M. (2012). Pollution Survey of Ikpoba River, Benin-City, Nigeria. Journal of Emerging Trends in Engineering and Applied Sciences (JETEAS) 3 (3): pp 567-571

7.Mohamed R. R. andMdYunnsRana (1996) Pollution Assimilative Capacity of Buriganga River. Journal of Civil Engineering, Institution of Engineers, Bangladesh. Vol. 24 (1) pp 85-95.

8. Streeter, H.W and Phelps, E.B (1925). A Study of the Pollution and Natural Purification of the Ohio River. Public Health Bulletin No 146. Public Health Service, Washington DC.

9. Theriault, E.J. (1927) The Dissolved Oxygen Demand of Polluted Waters. Public Health Bulletin No. 173 U.S public health service: Washington DC. 183

10.Thomann, R.V. and Muller J.A (1987) Principles of Surface water Quality modeling and control. Harper and Row :New York. pp 261-280

11. Thomas, H A. (1948). Pollution load capacity of streams. Water and sewage works 95: 409-413.

12. Fair, G.M. (1939). The Dissolved Oxygen Sag-An Analysis.Sewage works Journal11:445-461.

13. Li, W.H. (1962). Unsteady dissolved oxygen sag in streams. Journal of the Environmental Engineering division ASCE 88-75-85.

14. Gotowtsev, A.V. (2010). Modification of the StreeterPhelp system with the aim of account for the back between dissolved oxygen concentration and organic matter oxidation rate. Water Resources: 37. 245-251.

15. Camp, T.R (1968). Water and its Impurities. Reinhold Publishing corporation, New York, 287-310.

16. Dobbins, W.E. (1964). BOD and Oxygen Relationship in Stream.American society of civil engineers Journal of the Sanitary Engineering division. 90(6) , 53-78.
17. Owens, M. and Edwards R.W. (1963). Some Oxygen Studies in the River Lark, Society for Water Treatment and Exam., Proc. Vol. 12, p.126-145.

18. Edwards, R.W. and .Owens M. (1965). The Oxygen Balance of Streams, Fifth Symposium of British Ecological society: Oxford, Blackwell science publication p. 149-172.

19. Brown, L.C. and Banwell T.O. (1987). The Enhanced Stream Water Quality models QUAL2E and QUAL2EUNCAS: Documentation and User's Manual. Environmental Research Laboratory. U.S EPA: Washington DC.

20. Wool, T.A.; Ambrose R.B.; MartinJ.L; Comer, E.A; (2001). Water Quality Analysis simulation Program (WASP).version 6: user's manual. US Environmental Protection Agency, Region 4. Atlanta GA.

21. Gils, J.A.G Van and Argiropoulos, D. (1991). Axios River Basin Water quality Management, Water Resource Management vol.5, issue 3-4 pp 271-280

22.Agwunwamba, J.C. Maduka C.N and Ofusaren A.M. (2006).Analysis of pollution status of Amadi creek and its management.Journal of water supply: Research and Technology. AQUA (UK) 55 (6), pp 427-435

23. APHA, Standard Method for Examination of Water and Wastewater. American Public Health Association. 17th Ed. Port city Press, Baltimore, 1992,

24. HATCH, Digital Titration Handbook. HATCH Company USA 1991, pp 121

25. Buchanan, R.E and Gibbons, N.E eds.(1974) Bergey's Manual of Determinative Bacteriology $8^{\text {th }} E d$. Williams and Wilkins Co. Baltimore. pp 327-330

26. Lin, S.D. and Lee, C.C. (2007). Water and Wastewater calculations manual. McGraw Hill companies Inc. , USA. pp 14

27. Elmore, H.L. and Hays, T.W. (1960). Solubility of atmosphere oxygen in water.Journal of sanitation engineering division ASCE. 86. 41-53.

28. O'Connor, D. J; Dobbins, W.E. (1958). The Mechanism of Reaeration in Natural Streams.Journal of environmental engineering division ASCE. 123: 641684

29.Fair, G. M., Geyer, J. C., Okun, D. A.,(1968) Water and Wastewater Engineering. Vol. 2: Water Purification and Wastewater Treatment and Disposal, John Wiley, London 1968.

30.Hoang Ngoc, T.V and Tran Quang, L (2012).Assessment of Assimilative Capacity of Dong BA and Bach Yen River Branches, Hue City. Journal of Science, Hue University, Vol.70, No.1 pp 275-288

31. Ghagrekar, M.M (2013). Self-Purification of Natural Streams.Modul 12, Lecture Number-15.Indian Institute of Technology Kharagpur. pp2 
32. Nwankwor, G.I and Okpala, K.O (1993). SelfPurification Potentials of Small Tropical Urban Stream: A case study of River Nwaorie in Imo State. Environment Protection Engineering Vol. 19 No 1-4 pp 5-16

33. Igboanugo, A.C; Ezemonye, L.I.N; Chiejine, C.M. (2013). Influence of Effluent Discharge and Runoffs into Ikpoba River on its Water Quality. Nigerian Journal of Technology (NIJOTECH) Vol.32.No. 2. July2013. pp 294-303

34. Federal Environmental Protection Agency (FEPA) (1991).Guideline and Standard for Environmental Pollution Control in Nigeria.FG. Press pp.238.

35. M. Bosnic, J. Buljan(2000) Limits for discharge into water bodies and sewers US/RAS/92/120 Regional Programme for Pollution Control in the Tanning Industry in South-East Asia UNIDO publication

36. Jacobsen, B.N. and Warn, T. (1999): Overview and comparison of effluent standards for Urban wastewater treatment plants in European countries. European Water Management 2 (6), 25-39.

37. Tanzania Bureau of Standards, National Environmental Standards Compendium, Tanzania, 2005.

38. FEPA (1990)Interim Guidelines and Standards for Environmental Pollution Control in Nigeria

39. Malawi Bureau of Standards, 2005. Drinking water specifications, 1st revision, MS 214: 2005.
40. WHO, 2004.Guidelines for Drinking Water Quality. 3rdEdn. Vol. 1 Recommendation, Geneva, pp. 515.

APPENDIX: COMPARATIVE LIST OF EFFLUENT STANDARDS FOR DIFFERENT COUNTRIES OF THE WORLD

\begin{tabular}{clcccc}
\hline S/N & COUNTRY & $\begin{array}{c}\text { BOD } \\
\mathrm{mg} / \mathrm{l}\end{array}$ & $\begin{array}{c}\mathrm{COD} \\
\mathrm{mg} / \mathrm{l}\end{array}$ & $\mathrm{pH}$ & $\begin{array}{c}\text { SOUR } \\
\mathrm{CE}\end{array}$ \\
\hline 1 & Argentina & 50 & 250 & $5.5-10$ & {$[35]$} \\
2 & Australia & 40 & - & $6.0-9.0$ & {$[35]$} \\
3 & Brazil & 60 & - & $5.0-9.0$ & {$[35]$} \\
4 & China & 150 & 300 & $6.0-9.0$ & {$[35]$} \\
5 & Colombia & 800 & 1000 & $5.0-9.0$ & {$[35]$} \\
6 & Costa Rica & 400 & 600 & $5.9-9.0$ & {$[35]$} \\
7 & Czech Rep. & 50 & 300 & - & {$[35]$} \\
8 & Egypt & 500 & 100 & $6.0-9.0$ & {$[35]$} \\
9 & France & 25 & 125 & $5.5-8.5$ & {$[36]$} \\
10 & Germany & 25 & 250 & - & {$[35]$} \\
12 & Greece & $15-40$ & $45-150$ & $6.5-9.0$ & {$[35]$} \\
13 & Italy & 40 & 160 & $5.5-9.5$ & {$[36]$} \\
14 & Japan & 160 & 160 & $5.0-9.0$ & {$[35]$} \\
15 & Mexico & 200 & - & $6.0-9.0$ & {$[35]$} \\
16 & Kenya & 500 & 250 & $6.0-9.0$ & {$[35]$} \\
17 & Uganda & 30 & 100 & $6.0-8.0$ & {$[35]$} \\
18 & Tanzania & 30 & 60 & $6.5-8.5$ & {$[37]$.} \\
19 & Nigeria & 50 & - & $6.5-8.5$ & {$[38]$} \\
20 & South Africa & - & 30 & $5.5-9.5$ & {$[35]$} \\
21 & Spain & $40-300$ & $160-500$ & $5.5-9,5$ & {$[35]$} \\
22 & Zambia & 50 & 90 & $6.0-9.0$ & {$[35]$} \\
23 & Austria & 20 & 75 & $6.0-9.0$ & {$[36]$} \\
24 & Malawi & 20 & & $6.5-9.5$ & {$[39]$} \\
25 & W.H.O & 30 & 100 & $6.5-8.5$ & {$[40]$} \\
\hline
\end{tabular}

